\title{
Validation of Different Systems for Tumstatin Expression and its in-vitro and in-vivo Activities
}

\section{Chandra S Boosani', Ashok K Varma ${ }^{2}$ and Akulapalli Sudhakar ${ }^{1,3,4 *}$}

\author{
${ }^{1}$ Cell Signaling and Tumor Angiogenesis Laboratory, Department of Genetics, Boys Town National Research Hospital, Omaha, NE 68131, USA \\ ${ }^{2}$ Tata Memorial Center, Advanced Center for Treatment, Research and Education in Cancer, \\ Kharghar, Navi-Mumbai, Maharastra State 410210, India \\ ${ }^{3}$ Department of Biomedical Sciences, Creighton University School of Medicine, Omaha, NE 68131, USA \\ ${ }^{4}$ Department of Biochemistry and Molecular Biology, University of Nebraska Medical Center, Omaha, NE, 68198
}

\begin{abstract}
The aim of the present study is to identify an effective and efficient expression system for purification of recombinant antiangiogenic protein tumstatin. The sequence encoding carboxy-terminal non-collagenous domain of $\alpha 3$ chain Type IV collagen, $\alpha 3(\mathrm{IV}) \mathrm{NC} 1$ (tumstatin) was isolated from human placental tissue and cloned in three different expression vectors $\mathrm{pET} 22 \mathrm{~b}$, pcBFT and pAcHLTA to express it in bacteria, mammalian and $S f-9$ insect cells respectively. Expression and purification profiles of tumstatin were evaluated by coomassie staining and immunoblotting, and the efficiency was determined based on the yields of soluble protein. Our results indicate that, baculovirus expression system was efficient for scalable yields of soluble protein that could be purified in its biologically active form. This baculovirus expressed tumstatin was used to evaluate its anti-angiogenic and anti-tumarogenic functions such as inhibition of endothelial cell proliferation, cell viability, migration, tube formation, cap dependent protein translation and the associated signaling mechanism including in-vivo tumor study. Our evaluated approaches using a modified baculovirus expression system shows high expression and high yield of biologically active tumstatin, as compared to two expression systems, indicating baculovirus expression system to be an ideal method for bulk production of soluble tumstatin that needed for preclinical and clinical trails.
\end{abstract}

\section{Abbreviations}

Tumstatin: non-collagenous $\alpha 3$ chain of type IV collagen; AcNPV: Autographa californica nuclear polyhedrosis virus; Sf-9: Spodoptera frugiperda; HEK-293: Human Embryonic Kidney cells; mTOR: mammalian Target of Rapamycin and LLC lung lewis carcinoma.

\section{Introduction}

Vascular basement membrane (VBM) is an important constituent of blood vessels providing structural support (Darland and D'Amore, 1999). VBM was also speculated to modulate capillary endothelial cell behavior especially during sprouting of new capillaries (Darland and D'Amore, 1999). During matrix re-organization, several short protein fragments are generated from VBM by proteases. Some of these fragments were identified as inhibitors of angiogenesis (Boosani et al., 2007; Kalluri, 2003; O'Reilly et al., 1997; Petitclerc et al., 2000; Reynolds et al., 2002; Sudhakar, 2009; Sudhakar and Boosani, 2007;
Sudhakar and Boosani, 2008; Sudhakar et al., 2005). At present there are about 25 endogenous angioinhibitors in clinical trials and many more in preclinical studies for the treatment of cancer. These angioinhibitors fall into two general categories: (a) antibodies or small molecules that target pro-angiogenic factors of tumor cells such as VEGF, bFGF or PDGF, and (b) endogenous angioinhibitors such as thrombopondin-1, angiostatin, interferons, endostatin and some of the non collagenous (NC1) domains of Type IV collagen that target vascular endothelial cells (Boosani et al., 2007; O'Reilly et al., 1997; O'Reilly et al., 1994; Petitclerc et al., 2000; Qian et al., 1997; Sudhakar and Boosani, 2007; Sudhakar and Boosani, 2008; Sudhakar et al., 2005). This novel discovery of NC1 domains from human Type IV collagen as angioinhibitors initiated a new line of research in several laboratories and identified their significance for the treatment of cancer (Boosani et al., 2007; Boosani and Sudhakar, 2006; Borza et al., 2006; Maeshima et al., 2002; Marneros and Olsen, 2001; Petitclerc et al., 2000; Roth et al., 2005; Sudhakar and Boosani, 2007; Sudhakar et al., 2005; Sudhakar et al., 2003).

Tumstatin $(\alpha 3(\mathrm{IV}) \mathrm{NC} 1)$ a $28 \mathrm{kDa}$ cryptic domain is liberated from the carboxy terminal region of $\alpha 3$ chain type IV collagen by matrix metalloproteases was shown to inhibit proliferation of melanoma and epithelial tumor cell lines in-vitro by binding to $\mathrm{CD} 47 / \alpha \mathrm{V} \beta 3 / \alpha 3 \beta 1$ integrin complex (Boosani et al., 2007; Borza et al., 2006; Han et al., 1997; Hemmings, 1997; Maeshima et al., 2000; Monboisse et al., 1994; Petitclerc et al., 2000; Qian et al., 1997; Shahan et al., 1999; Sudhakar and Boosani, 2007; Sudhakar et al., 2003). We previously reported that tumstatin binds to $\alpha \mathrm{V} \beta 3 / \alpha 3 \beta 1$ integrins and inhibits $\mathrm{PI} 3 \mathrm{~K} / \mathrm{Akt} / \mathrm{mTOR} /$ 4E-BP1/COX-2 signaling leading to the inhibition of protein synthesis and hypoxic tumor angiogenesis (Boosani et al., 2007; Maeshima et al., 2002; Sudhakar et al., 2003). Tumstatin

\begin{abstract}
*Corresponding author: Dr. Sudhakar Akulapalli, Assistant Professor/Staff Scientist II, Creighton University School of Medicine and University of Nebraska Medical Center, Director \& Coordinator: Cell Signaling and Tumor Angiogenesis Laboratory, Boys Town National Research Hospital, $555 \mathrm{~N}$, 30th Street, Omaha NE 68131, Tel: (402) 498-6681, (402) 498-6322; Fax: (402) 498-6331; E-mail: akulapallis@boystown.org
\end{abstract}

Received November 19, 2009; Accepted November 27, 2009; Online published November 27, 2009; Published July 02, 2010

Citation: Boosani CS, Varma AK, Sudhakar A (2009) Validation of Different Systems for Tumstatin Expression and its in-vitro and in-vivo Activities. J Cancer Sci Ther 1: 008-018. doi:10.4172/1948-5956.1000002

Copyright: ( $) 2009$ Boosani CS, et al. This is an open-access article distributed under the terms of the Creative Commons Attribution License, which permits unrestricted use, distribution, and reproduction in any medium, provided the original author and source are credited. 

vivo Activities. J Cancer Sci Ther 1: 008-018. doi:10.4172/1948-5956.1000002

was also reported to inhibit tumor angiogenesis and tumor growth in mice by up-regulating apoptosis in endothelial cells (Petitclerc et al., 2000). These studies indicate that tumstatin has complex signaling mechanisms in regulating tumor angiogenesis which are to be explored, and for such studies a suitable expression system is needed to over express and purify the protein in its biologically active form.

In the present study, we isolated the coding sequence of tumstatin from human placenta, expressed it in three different expression systems and compared the expression and purification strategies in obtaining the recombinant protein in a biologically active suitable form for in-vitro and in-vivo studies. Among the three systems tested, baculovirus expression system was found effective for production of soluble tumstatin protein. This expression system provides ambient conditions for proper folding, disulfide bond formation and oligomerization of the over expressed recombinant proteins besides correct post-translational modifications. Baculovirus expressed purified tumstatin protein when tested showed its characteristic angioinhibitory functions such as inhibition of endothelial cell proliferation, translation, tube formation and the associated signaling pathway including inhibition of tumorangiogenesis in LLC tumors. Our studies demonstrate that the baculovirus expression system is ideal for bulk production of tumstatin in its biologically active form, and this method may be suitable for bulk production of this angioinhibitor for pre-clinical and future clinical studies.

\section{Materials and Methods}

Baculovirus transfer vector pAcHLT-A, transfecting agent lipofectin, Affinity matrix (Ni-NTA agarose) were obtained from PharMingen, USA. The plasmid pBlueScriptII-SKplus (pBSIISKP) was purchased form Stratagene. Plasmid pET22b expression vector was purchased from Novagen. Recombinant human bFGF and VEGF were obtained from R\&D systems. Horseradish peroxidase (HRP)-labeled secondary antibodies, penicillin/streptomycin, fibronectin (FN) low melting Agarose and neutral red staining solution and sepharose beads were obtained from Sigma-Aldrich. Primary HUVECs were purchased from Clonetech ${ }^{\mathrm{TM}}$ Inc and LLC tumor cells were purchased from ATCC (CRL-1642). BD Martigel ${ }^{\mathrm{TM}}$ (14.6 mg/ml) was purchased from BD Biosciences Discovery lab. Recombinant human endostatin was obtained from R\&D Systems (Minneapolis, MN). Graces insect cell culture medium, cell fixer and staining H\&E and X-Ray films (Kodak) were purchased from Fisher Scientific Inc. Protease inhibitor solutions were purchased from Boehringer and Mannheim, GmbH. FCS, ECL Kit, Random primer labeling kit, hybond $\mathrm{N}^{+}$membrane, $\left[\gamma^{32} \mathrm{P}\right] \mathrm{dCTP}$, DNA ladder, competent cells, DNA polymerase I, klenow fragment and Multiprime DNA labeling system were purchased from Amersham Biosciences. Trizol, ThermoScript RT-PCR system, Lipofectamine Plus, E. coli strain BL21(DE3)AI and $P f x$ polymerase reagent were obtained from Invitrogen. Restriction enzymes were obtained from New England Biolabs.

\section{Cell culture}

Primary HUVECs were maintained in EGM-2 medium at $37^{\circ} \mathrm{C}$ in a humidified 5\% $\mathrm{CO}_{2}$ incubator. HUVECs passages 3-5, were used for studies. LLC cells were maintained in DMEM medium supplemented with $10 \%$ FCS with $100 \mu \mathrm{g} / \mathrm{ml}$ of antibiotic and antimycotic solution. $S f-9$ cells were grown as monolayer cultures in TNM-FH medium supplemented with $10 \%$ FCS and with $100 \mu \mathrm{g} / \mathrm{ml}$ of antibiotic and antimycotic solution. Sf-9 cell viability was tested and cell cultures with above $95 \%$ cell viability were used for transfection and expression studies. $S f-9$ ells were fed with fresh culture medium for every two days and were passed routinely at $80 \%$ confluence.

\section{Isolation and characterization of recombinant tumstatin clones}

Total RNA was isolated from human placental tissue using Trizol, and cDNA synthesis was carried out using ThermoScript RT-PCR system following manufacturer's guidelines. The coding sequence corresponding to $\alpha 3$ Type IV NC1 (720 bp, GenBank accession number EU268882) was PCR amplified from

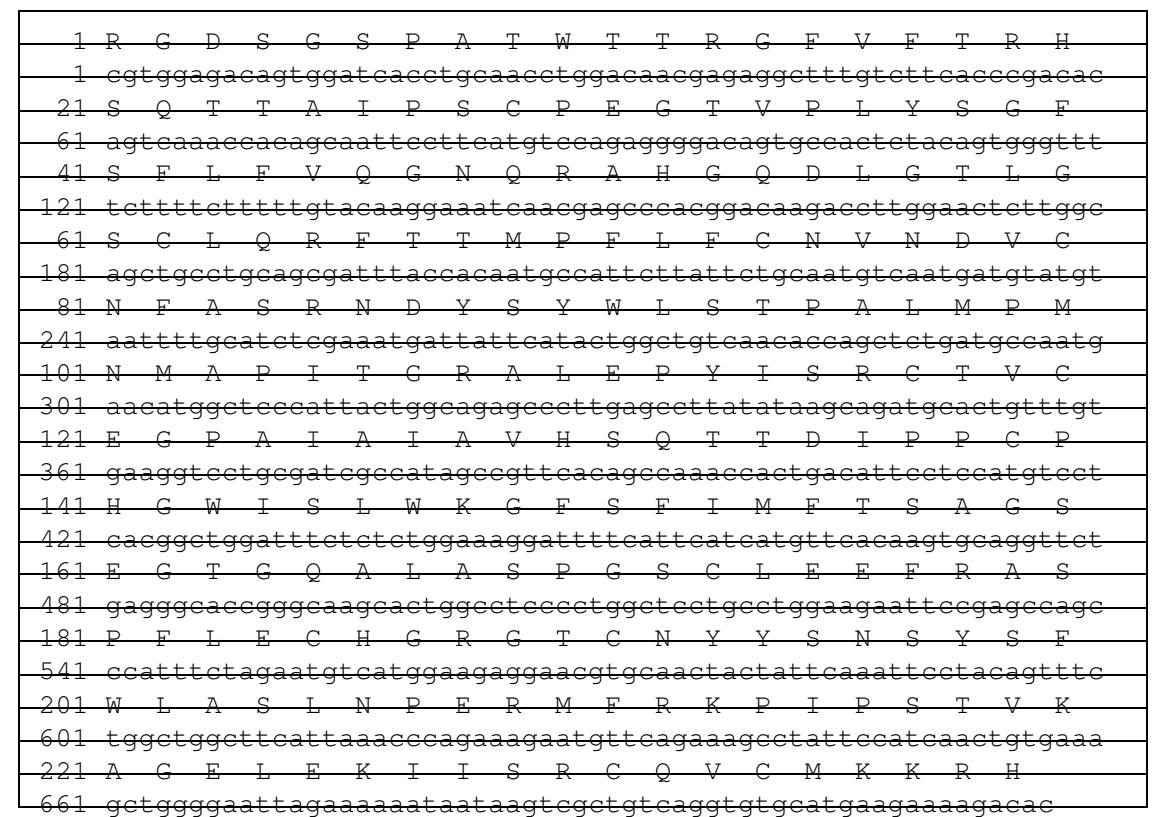

Table 1: Human tumstatin coding sequence and translation map 


\section{Journal of Cancer Science \& Therapy - Open Access}

JCST/Vol.1 Issue 1

the above cDNA using Platinum $P f x$ polymerase and Forward primer 5'-CCGTGGAGACAGTGGATC-3' and Reverse primer 5'-GTGTCTTTTCTTCATGCACA-3' sequences. PCR amplification was performed in PTC-100 Programmable Thermal Controller from MJ Research Inc, with an initial denaturation at $94^{\circ} \mathrm{C}$ for $2 \mathrm{mins}$, followed by 35 cycles of " $94^{\circ} \mathrm{C} / 1 \mathrm{~min}-58^{\circ} \mathrm{C} /$ $1 \mathrm{~min}-68^{\circ} \mathrm{C} / 1 \mathrm{~min}$ ", and with final extension at $68^{\circ} \mathrm{C} / 5 \mathrm{mins}$. The resulting amplicon was cloned at EcoRV site in pBlueScriptIISKplus vector and the recombinant clones "pBSIISK/ tumstatin" were identified by blue white selection. The recombinant clones "pBSIISKP/tumstatin" were sequenced using high-throughput DNA sequencing facility at University of Nebraska Medical Centre (UNMC) and the sequence was confirmed following a BLAST search. The translation map of tumstatin coding sequence was shown in Table 1.

\section{Cloning and expression of tumstatin in $S f-9$ insect cells}

The sequence encoding human tumstatin was PCR amplified from the plasmid vector pBSIISK/tumstatin using $P f x$ polymerase and forward primer (5'-CGCCATATGCCGTGGAGACA GTGGATC-3') and reverse primer (5'-GCGAGATCTTCA GTGTCTTTTCTTCATGCACA-3') sequences that were modified to incorporate Nde I and $\mathrm{Bgl}$ II restriction sites. The resulting amplicon was digested with Nde I and Bgl II restriction enzymes and ligated into baculovirus transfer vector pAcHLTA (BD PharMingen) predigested with the same restriction enzymes. The recombinant baculovirus transfer vector harboring Tumstatin, pAcHLT-A/tumstatin with 6xHis tag located Nterminal to tumstatin (enables simple one-step protein purification using Ni-NTA agarose affinity chromatography) were screened through colony hybridization and autoradiography as reported earlier by us (Boosani et al., 2007; Boosani and Sudhakar, 2006; Sudhakar et al., 1999; Sudhakar et al., 2000). The recombinant transfer vector pAcHLT-A/tumstatin was cotransfected with Bsu361 digested linearized Baculogold ${ }^{\mathrm{TM}}$ (Cat No: 21100D) viral DNA into $S f-9$ cells using Bacfectin to obtain an infectious complete viral genome (Boosani et al., 2007; Boosani and Sudhakar, 2006; Sudhakar et al., 1999; Sudhakar et al., 2000). After $72 \mathrm{hr}$ of co-transfection the medium supernatant containing recombinant viral particles harboring tumstatin was collected and used in plaque assay, where six out of 18 plaques tested were found positive. The recombinant virus harboring tumstatin was confirmed by dot-blot hybridization using the radioactive probe corresponding to 720 bp tumstatin cDNA, similarly to our earlier reports (Boosani et al., 2007; Boosani and Sudhakar, 2006; Sudhakar et al., 1999; Sudhakar et al., 2000). Positive recombinant virus identified from dot blot hybridization was used for further amplification of virus and a high viral titer (MOI-10) was used to infect $S f-9$ cells for expression studies as reported previously (Boosani et al., 2007; Boosani et al., 2009b; Boosani and Sudhakar, 2006; Sudhakar et al., 1999; Sudhakar et al., 2005; Sudhakar et al., 2000). Sf-9 cells after $72 \mathrm{hrs}$ of post infection were washed twice with ice cold PBS ( $\mathrm{pH}$ 6.2) and lysed in buffer containing $20 \mathrm{mM}$ tris-Hcl pH 7.8, $250 \mathrm{mM} \mathrm{NaCl}, 1 \mathrm{mM} \mathrm{MgCl}, 1 \mathrm{mM}$ DDT, $0.2 \%$ TritonX-100 and $1 \mathrm{x}$ complete protease inhibitor cocktail (Roche). The lysate was centrifuged at $13000 \mathrm{rpm}$ for $30 \mathrm{~min}$ at $4^{\circ} \mathrm{C}$ and the clear supernatant containing recombinant protein was quantified and analyzed by SDS-PAGE before being used for protein purification.

\section{Metal affinity purification of tumstatin}

Lysate containing about $40 \mathrm{mg}$ of total protein was mixed with Ni-NTA agarose affinity matrix ( $1 \mathrm{ml}$ bed volume, binding capacity $20 \mathrm{mg} / \mathrm{ml}$ ), and incubated for $1 \mathrm{hr}$ at $4^{\circ} \mathrm{C}$ on a rocker and centrifuged at $500 \mathrm{xg}$ for $5 \mathrm{~min}$ at $4^{\circ} \mathrm{C}$. The supernatant was discarded and the matrix with bound protein was washed once with lysis buffer containing $1 \mathrm{x}$ complete protease inhibitor cocktail, and then thrice with wash buffer containing $100 \mathrm{mM}$ $\mathrm{NaH}_{2} \mathrm{PO}_{4}, 10 \mathrm{mM}$ Tris $\mathrm{HCl}, 250 \mathrm{mM} \mathrm{NaCl}$ and $50 \mathrm{mM}$ Imidazole and $1 \mathrm{x}$ complete protease inhibitor cocktail (Roche), final $\mathrm{pH}$ 8.0. The $6 x$ His-tagged tumstatin protein bound to the matrix was eluted in elution buffer containing $100 \mathrm{mM} \mathrm{NaH}_{2} \mathrm{PO}_{4}, 250$ $\mathrm{mM} \mathrm{NaCl}$ and $250 \mathrm{mM}$ Imidazole and $1 \mathrm{x}$ complete protease inhibitor cocktail (Roche) final pH 8.0. For purification of E. coli expressed tumstatin protein, the above wash and elution buffers were supplemented with $3 \mathrm{M} \mathrm{GuHCl}$ and $4 \mathrm{M}$ Urea. Tumstatin expressed in Sf-9 cells has an $\mathrm{N}$-terminal 6xHis tag and a downstream thrombin cleavage site to remove $6 \times$ His tag by Thrombin digestion. The same protein expressed in E. coli has 6 xHis tag at C-terminal end without any thrombin cleavage site. The protein eluted from the affinity matrix was dialyzed and concentrated by $0-80 \%$ ammonium sulphate precipitation. Both soluble and insoluble protein was suspended in equal volume of PBS and stored at $-80^{\circ} \mathrm{C}$. Concentration of soluble and insoluble protein was quantified using Biorad protein assay kit and analyzed on SDS-PAGE.

\section{Cloning and expression of tumstatin in $E$. coli BL21(DE3)AI}

The coding sequence corresponding to tumstatin was amplified from "pBSIISK/tumstatin" using $P f x$ polymerase, and the following primer sequences that were modified to incorporate NdeI and XhoI restriction sites; forward primer (5'CGCCATATGCGTGGAGACAGTGGATC-3') and reverse primer (5'-GCGCTCGAGGTGTCTTTTCTTCATGCACA-3'). The amplicon was digested and cloned at the same sites in pET22b, upstream to 6xHis tag. The recombinant plasmid "pET22b/ tumstatin" was used to transform E. coli BL21(DE3)AI for expression. A 1:100 dilution of the overnight starter culture was used to inoculate 1 liter culture in LB (Laura Bertani) medium and the culture was grown for $2 \mathrm{hr}$ at $220 \mathrm{rpm}$ and $37^{\circ} \mathrm{C}$, where the cells reached an O.D $\mathrm{A}_{600}$ of 0.421 . The expression of the recombinant protein was induced by addition of $1 \mathrm{mM}$ isopropyl-1-thio- $\beta$-D-galactopyranoside (IPTG) and $1 \%$ L-Arabinose with further incubation for $4 \mathrm{hr}$ at $220 \mathrm{rpm}$ and $37^{\circ} \mathrm{C}$. The induced culture was then centrifuged at $3000 \mathrm{rpm}$ for $10 \mathrm{mins}$ and the bacterial cell pellet was suspended in buffer containing $100 \mathrm{mM} \mathrm{NaH}_{2} \mathrm{PO}_{4}, 10 \mathrm{mM}$ Tris $\mathrm{HCl}$ and $250 \mathrm{mM} \mathrm{NaCl}(\mathrm{pH}$ 7.6). The bacterial suspension was sonicated on ice and centrifuged at $13000 \mathrm{rpm}$ for $30 \mathrm{~min}$ at $4^{\circ} \mathrm{C}$. The resulting bacterial pellet containing recombinant protein was suspended in lysis buffer containing $3 \mathrm{M}$ Guanidine, $4 \mathrm{M}$ urea, $100 \mathrm{mM} \mathrm{NaH}_{2} \mathrm{PO}_{4}$, $10 \mathrm{mM}$ Tris $\mathrm{HCl}$ and $250 \mathrm{mM} \mathrm{NaCl}$ (pH 7.6) and centrifuged at $13 \mathrm{~K}$ for $30 \mathrm{mins}$ at $4^{\circ} \mathrm{C}$. The clear supernatant obtained after centrifugation was used for protein purification using metal affinity purification as stated above.

\section{Cloning, expression and purification of tumstatin in HEK-} 293 cells

The coding sequence of tumstatin was amplified from pBSIISK/tumstatin using forward primer (5'-CGCGGATCCCGT
Volume 1(1) : 008-018 (2009) - 010 
Citation: Boosani CS, Verma AK, Sudhakar A (2009) Validation of Different Systems for Tumstatin Expression and its in-vitro and invivo Activities. J Cancer Sci Ther 1: 008-018. doi:10.4172/1948-5956.1000002

GGAGACAGTGGATC-3') and reverse primer (5'-GCGCTCG AGGTGTCTTTTCTTCATGCACA-3') sequences, and cloned in frame at BamHI and XhoI sites of mammalian expression vector pcBFT downstream to BM40 secretion tag, Flag tag and Thrombin cleavage sites. The recombinant vector pcBFT/ tumstatin was used to transfect HEK-293 (human embryonic kidney) cells using lipofectamine plus reagent. The transfected cells were selected using G418 (500 $\mu \mathrm{g} / \mathrm{ml})$ and the resistant colonies were cultured in $150 \mathrm{~mm}$ culture plates containing DMEM-F12 medium. When the cells reached about 90\% confluence they were fed with serum free medium and after every $48 \mathrm{hrs}$ medium supernatant was collected, pooled and stored at $4^{\circ} \mathrm{C}$. About 2 liters of medium supernatant containing the secreted recombinant tumstatin protein was concentrated by $0-80 \%$ ammonium sulphate precipitation and the resulting pellet was dissolved in $4 \mathrm{ml}$ of buffer containing $20 \mathrm{mM}$ Tris$\mathrm{Hcl} \mathrm{pH} \mathrm{7.8,} 2 \mathrm{mM} \mathrm{Mg}(\mathrm{OAc})_{2}, 50 \mathrm{mM} \mathrm{KCl}, 5 \%$ glycerol and 100 $\mu \mathrm{M}$ EDTA, and subjected to sepharose immunoaffinity chromatography using anti-tumstatin antibody. The affinity column was washed twice with $50 \mathrm{mM} \mathrm{KCl}$ buffer and the bound tumstatin protein was eluted with $0.4 \mathrm{M} \mathrm{KCl}$ buffer as described previously (Gunwar et al., 1991; Neilson et al., 1993). The total eluted protein was digested with Thrombin to remove BFT sequence, dialyzed and concentrated by $0-80 \%$ Ammonium sulphate precipitation and both insoluble and soluble protein was suspended in equal volume of PBS as described above.

\section{Proliferation assay}

A suspension of about 5.0x $10^{4} \mathrm{HUVECs} /$ well in a 24 well plate were serum starved, trypsinized and transferred to a fresh 24-well plate pre-coated with fibronectin and cultured for $24 \mathrm{hr}$ in EGM-2 medium containing various concentrations of recombinant baculovirus expressed tumstatin. After $24 \mathrm{hr}$ of treatment $1 \mu 1$ of $\left[{ }^{3} \mathrm{H}\right]$-thymidine was added into each well and incubated further for $72 \mathrm{hr}$ at $37^{\circ} \mathrm{C} .\left[{ }^{3} \mathrm{H}\right]$-thymidine incorporation as a direct means of cell proliferation was measured using scintillation counter as described previously by us (Boosani and Sudhakar, 2006; Sudhakar et al., 2005; Sudhakar et al., 2003).

\section{Protein synthesis assay}

Cells were serum starved for $24 \mathrm{hr}$ and then stimulated with $10 \% \mathrm{FCS}$ in presence of baculovirus expressed tumstatin for $48 \mathrm{hr}$. Cells were pre-incubated in methionine-free medium for $1 \mathrm{hr}$ and then incubated in culture medium containing radioactive methionine for $1 \mathrm{hr}$ at $37^{\circ} \mathrm{C}$. The incorporation of radioactivity into trichloroacetic acid precipitates was analyzed as described previously (Maeshima et al., 2002; Sudhakar et al., 2003). ANOVA with a one tailed student's $t$ test was scored to identify significant differences in multiple comparisons in the present study. A level of $P<0.05$ was considered statistically significant.

\section{3-(4,5-Dimethylthiazol-2-yl)-2,5-diphenyl tetrazoliumbromide assay (MTT)}

HUVECs, about $8 \times 10^{3}$ cells/well, were plated on a 96-well plate in EGM-2 medium. After $24 \mathrm{hr}$, various concentrations of baculovirus expressed tumstatin was added, and after $24 \mathrm{hr}$ of incubation cell viability was assessed by MTT assay, following our previously described protocols (Boosani and Sudhakar, 2006).

\section{Migration assay}

About $1 \times 10^{4}$ HUVECs in $30 \mu 1$ of incomplete medium were pre treated with and without baculovirus expressed recombinant tumstatin protein $(1 \mu \mathrm{M})$ and seeded into each upper well of the Boyden chamber. In the lower wells of Boyden chamber, ICM containing $25 \mathrm{ng} / \mathrm{ml} \mathrm{bFGF}$ was added and the cells were incubated for $24 \mathrm{hr}$ at $37^{\circ} \mathrm{C}$ with $5 \% \mathrm{CO}_{2}$ ICM alone was used as negative control. $\alpha 1$ (IV)NC1 $(1 \mu \mathrm{M})$ was used as control since it is a known inhibitor of endothelial cell migration. The number of cells that migrated and attached to the under side of the membrane were stained with $\mathrm{H} \& \mathrm{E}$ and observed through Olympus CK2 light microscope as reported (Boosani et al., 2009a; Sudhakar et al., 2005; Sudhakar et al., 2003).

\section{Tube formation assay}

Matrigel matrix was thawed overnight at $4^{\circ} \mathrm{C}$ and $250 \mu \mathrm{l}$ of matrigel matrix added to each well of a chilled 24 well plate and allowed to polymerize for $30 \mathrm{~min}$ at $37^{\circ} \mathrm{C}$. A suspension of $5 \times 10^{4}$ HUVECs in EGM-2 without antibiotics was plated on top of the matrigel coated wells and the cells were treated with or without $1.0 \mathrm{mM}$ baculovirus expressed tumstatin or arresten (control). After incubation for $48 \mathrm{hr}$ at $37^{\circ} \mathrm{C}$, tube formation was observed using Olympus CK2 light microscope as reported (Boosani et al., 2009a; Sudhakar et al., 2003).

\section{Cell signaling experiments}

About $10^{6}$ HUVECs were seeded on a $10 \mathrm{~cm}^{2}$ petridish coated with fibronectin and the monolayer culture was pre-incubated with baculovirus expressed tumstatin $(1 \mu \mathrm{M})$ or endostatin $(1$ $\mu \mathrm{M})$ for $0-60 \mathrm{~min}$. The cells were then lysed in $200 \mu \mathrm{l}$ of lysis buffer containing $20 \mathrm{mM}$ tris-Hcl pH 7.8, $1 \mathrm{mM} \mathrm{Mg}^{2+}, 1 \mathrm{mM}$ DDT, $1 \mathrm{X}$ pepstatin A, $1 \mathrm{X}$ leupeptin, $1 \mathrm{X}$ aprotinin, $1 \mathrm{mM}$ PMSF and $80 \mathrm{mM} \mathrm{KCl}$. Cell extracts were separated on a $10 \%$ SDSPAGE and transferred onto a nitrocellulose membrane by western blotting. The proteins involved in the anti-angiongenic signaling were evaluated following immunoblotting using phosphorylated and unphosphorylated antibodies specific to FAK (tyr397; BioSource International.), Akt (Ser473; New England Biolabs Inc.), mTOR (ser 2448; Cell Signaling), 4E-BP1 (thr 37/46; Cell Signaling) proteins, similar to our previous studies (Boosani et al., 2007; Maeshima et al., 2002; Sudhakar et al., 2005; Sudhakar et al., 2003).

\section{In-vitro kinase assay for mTOR activity}

Phosphorylation of mTOR and GST-4EBP-1 fusion protein (mTOR substrate) was evaluated in HUVECs transfected with HA-mTOR/FRAP expression vector. Briefly, HUVECs were serum-starved and transiently transfected with HA-mTOR/FRAP plasmid using Lipofectamine Plus reagent (Invitrogen, Carlsbad, CA). Transfected HUVECs $\left(4 \times 10^{6}\right.$ cells) were treated with equimolar concentrations of baculovirus expressed tumstatin or endostatin for $24 \mathrm{hr}$ as explained earlier (Maeshima et al., 2002; Sudhakar et al., 2003). The cells were lysed and 200 $\mu \mathrm{g}$ of extracts was subjected to immunoprecipitation with antiHA antibody (Boosani et al., 2007; Sudhakar et al., 2003). HAmTOR/Anti-HA complexes were incubated with recombinant GST-4E-BP1 fusion protein in presence of $10 \mu \mathrm{Ci}$ of $\left[\gamma^{32} \mathrm{P}\right] \mathrm{dCTP}$ in kinase buffer. The reactions were terminated by boiling and the samples were subjected to $10 \%$ SDS-PAGE and western 


\section{Journal of Cancer Science \& Therapy - Open Access \\ JCST/Vol.1 Issue 1}

A

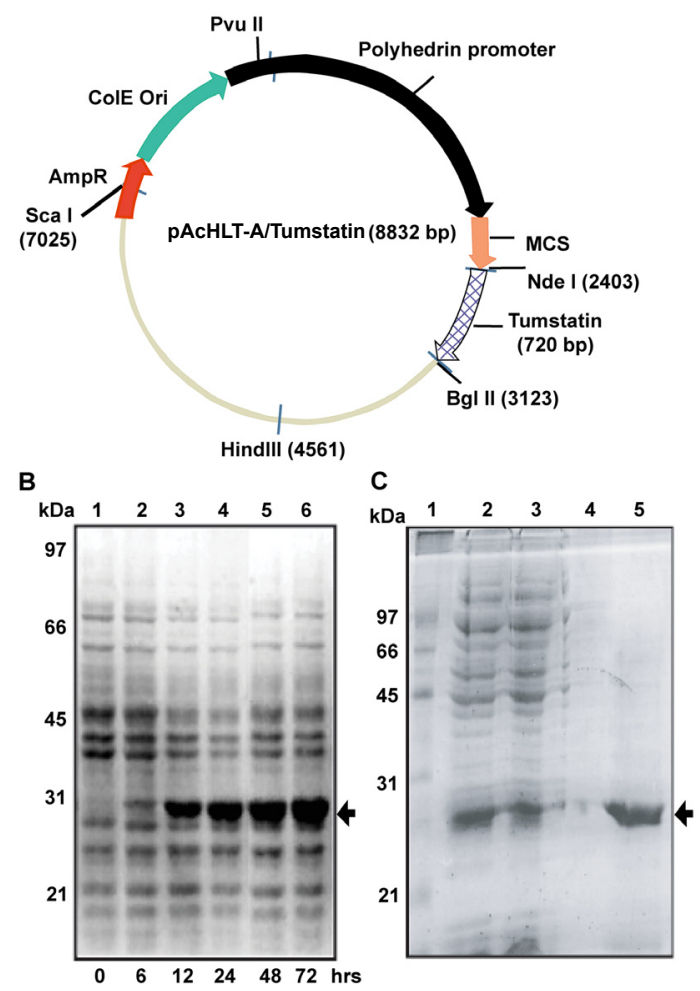

Figure 1: Expression and purification of tumstatin in $S f-9$ insect cells.

(A) pAcHLT-A harboring tumstatin: The 720 bp coding sequence corresponding to tumstatin was cloned between Nde I and Bgl II sites of baculovirus transfer vector, pAcHLT-A. (B) Time course expression of tumstatin in $S f_{-9}-9$ cells: Each lane contains about $30 \mu \mathrm{g}$ of total $S f-9$ cells extract. Lane 1 shows cell extracts at $0 \mathrm{hr}$ time point (control). Lanes 2, 3, 4, 5 \& 6 represent $S f-9$ cell extracts from 6, 12, 24, $48 \& 72 \mathrm{hr}$ of tumstatin baculovirus post infection time points. (C) Solubility of tumstatin protein expressed in $\boldsymbol{S f}$-9 cells: Lane 1 shows molecular weight marker; lane 2 and 3 show $10 \mu \mathrm{l}$ of flow through; lanes 4 and 5 show insoluble and soluble tumstatin protein (total soluble and insoluble tumstatin protein was suspended in equal volume of PBS and $10 \mu \mathrm{l}$ was loaded in each lane of the gel. B and C are coomassie stained 10\% SDS-PAGE gel. Arrows in $\mathrm{B}$ and $\mathrm{C}$ indicate tumstatin protein

immunobloted as reported (Boosani et al., 2007; Maeshima et al., 2002; Sudhakar et al., 2005; Sudhakar et al., 2003). The phosphorylated proteins of mTOR-P and GST-4EBP1-P were detected by autoradiography as described previously (Gingras et al., 2001; Kumar et al., 2000; Maeshima et al., 2000; Maeshima et al., 2002; Sudhakar et al., 2003).

\section{Immunohistochemical staining}

Briefly, 4-mm frozen tumor sections were fixed in $100 \%$ acetone for $3 \mathrm{~min}$ at $-20^{\circ} \mathrm{C}$ and air-dried. The tumor sections were incubated with primary rat anti-mouse CD31 antibody at room temperature for $1 \mathrm{hr}$. Subsequently, tumor sections were washed with PBS and incubated with tetramethyl rhodamine-conjugated secondary antibody at same conditions about $1 \mathrm{hr}$. In each group, the numbers of CD31-positive blood vessels were counted in 10 fields in a blinded fashion as previously described (Sudhakar et al., 2005).

\section{In-vivo tumor studies using C57BL/6 mice}

Sixteen male four months old mice were used for this tumor study. Mice backs were shaved and about $1.0 \times 10^{6}$ LLC cells were injected subcutaneously into the back of each mouse. Ten days after tumor cells implantation, the mice were divided into 2 groups ( 8 each). For the experimental group, tumstatin was intravenously injected daily at $1 \mathrm{mg} / \mathrm{kg}$ per body weight or $30 \mu \mathrm{g}$ per mouse, while only sterile PBS was injected into the control group mice. When control mice tumors reached about $2.0 \mathrm{~cm}^{3}$, mice were sacrificed and the tumors were frozen for histological analysis (Boosani et al., 2007; Martin and Evans, 1975; Sudhakar et al., 2005).

\section{Measurement of circulating endothelial cells}

About $400 \mu \mathrm{l}$ of control and tumstatin treated tumor bearing mice blood was collected before scarifying in EDTA/heparin containing microcentrifuge tubes. Blood plasma was separated and $300 \mu \mathrm{l}$ of DMEM supplemented with $10 \%$ FBS was added to each tube. Red blood cells were removed with RBC lysis solution and the mixture was placed on 8-chamber slides about $6 \mathrm{hr}$ and incubated at $37^{\circ} \mathrm{C}$. The attached endothelial cells were stained with anti-VEGFR2 antibody as reported (Boosani et al., 2007). The positive cells were counted under the fluorescence microscope in 10 fields at a magnification of $200 \mathrm{X}$ as reported (Boosani et al., 2007).

\section{Statistical Analysis}

Statistical differences between control and tumstatin treated LLC tumor groups were calculated using Student's t test. Analysis of variance (ANOVA) was used to determine statistical differences among the groups. A p value $<0.001$ was considered statistically significant.

\section{Results and Discussion}

In the present work, we show evaluation of the purification systems and the methods employed in obtaining the recombinant protein in a biologically active form through cloning, expression and purification of $\alpha 3$ chain type IV collagen noncollagenous domain (tumstatin) using three different expression systems. The purification profiles and strategies were compared for their efficiencies in yield and biological activity of baculovirus expressed tumstatin in-vitro and in-vivo.

\section{Purification of tumstatin from $S f-9$ cell cultures}

The recombinant baculovirus transfer vector pAcHLT-A/ tumstatin (Figure 1A) was co-transfected with linearized Baculogold viral DNA into $S f-9$ cells to obtain an infectious complete viral genome. About $2 \times 10^{6} \mathrm{Sf}-9$ cells were transfected with recombinant virus (MOI-10) and extracts were prepared from $0,12,24,48$ and 72 hrs of post-infection as reported earlier (Boosani and Sudhakar, 2006; Sudhakar et al., 1999; Sudhakar et al., 2000). Sf-9 cell extracts were analyzed on a $10 \%$ SDS-PAGE gel to monitor the time course expression of tumstatin, where a single band corresponding to $28 \mathrm{kDa}$ was detected whose concentration increased with increase in postviral infection time (Figure 1B, lanes 2 to 6 ). Where as wild type AcNPV virus infected $S f-9$ cells did not show any such expression (data not shown). The over expressed protein cross reacted with anti-tumstatin antibody as observed through Western blotting (data not shown). The coomassie stained gel detailing the purification profile of recombinant tumstatin was shown, wherein about $10 \mu \mathrm{g}$ of total protein from each fraction collected during the purification process was loaded 


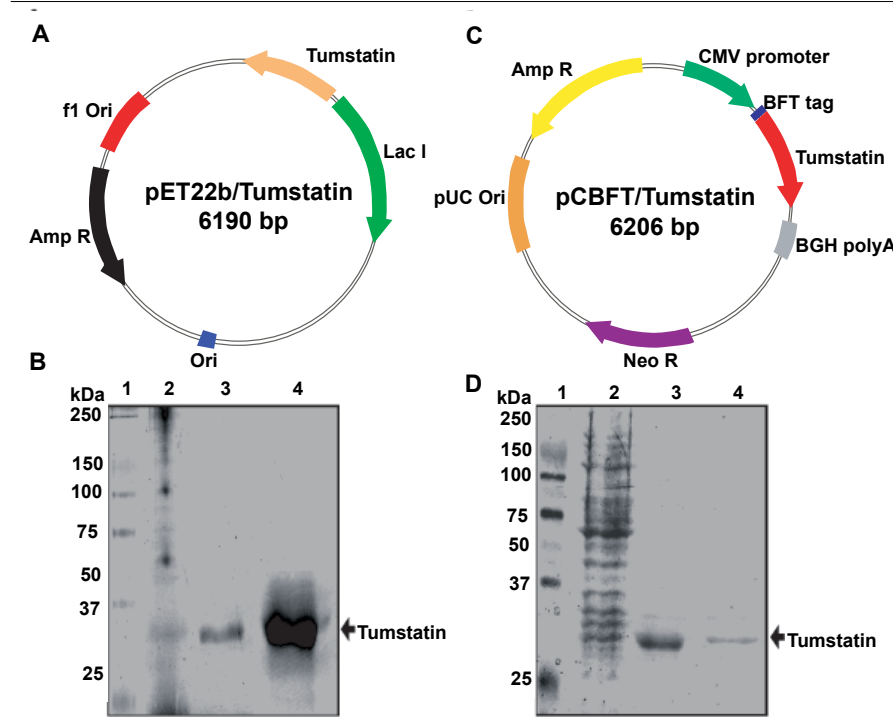

Figure 2: Expression of tumstatin in E. coli and mammalian cells. (A) Vector map of pET22b harboring tumstatin: Tumstatin was cloned between NdeI and XhoI sites of bacterial expression vector pET22b. (B) E. coli expressed solubile tumstatin protein: Lane 1, shows molecular weight marker; lane 2 shows about $10 \mu \mathrm{l}$ of column flow through; lane 3 and 4 show total insoluble and soluble tumstatin protein (total soluble and insoluble tumstatin protein suspended in equal volume of PBS and $2 \mu 1$ was loaded in each lane). (C) Vector map of plasmid pcBFT harboring tumstatin: Tumstatin was cloned in frame between BamHI and XhoI sites of mammalian expression vector, pcBFT. (D) HEK-293 cell expressed soluble tumstatin: Lane 1 is a molecular weight marker; lane 2 shows cytosolic extracts from HEK-293 cells; lanes 3 and 4 show soluble and insoluble tumstatin fractions similar to B. B and D are coomassie stained $10 \%$ SDS-PAGE gel.

in each well of the gel (Figure 1C, lanes 2-3). The Ni-NTA column bound tumstatin protein was eluted, dialyzed and concentrated by $0-80 \%$ ammonium sulphate precipitation. About $2 \mu \mathrm{l}$ of insoluble and soluble tumstatin protein was diluted in $10 \mu \mathrm{l}$ of PBS and analyzed on $10 \%$ SDS-PAGE gel to compare their yields (Figure 1C, lanes 4-5).

\section{Purification of tumstatin using bacterial expression system}

The tumstatin coding sequence was cloned in frame in pET22b, which resulted in the recombinant plasmid "pET22b/ tumstatin" (Figure 2A). Chemically competent BL21(DE3)AI cells were transformed with "pET22b/tumstatin" and a single colony derived log phase culture was induced with $1 \mathrm{mM}$ IPTG and $0.2 \%$ L-Arabinose. E. coli cell extracts from different time intervals were analyzed. The time course expression of tumstatin in $E$. coli was studied to identify the post induction time at which maximum protein induction is observed. The expression of tumstatin protein increased with increase in post induction time (data not shown). After induction, bulk extracts from 1 liter culture were prepared for protein purification using Ni-NTA column as described in the methods section. About 10 $\mu \mathrm{g}$ of total protein from each collected fraction was analyzed on a $10 \%$ SDS-PAGE (Figure $2 \mathrm{~B}$ ). About $2 \mu \mathrm{l}$ of insoluble and soluble tumstatin protein was diluted to $10 \mu \mathrm{l}$ in PBS and analyzed on a 10\% SDS-PAGE gel to compare their yields (Figure 2C, lanes 4-5).

\section{Purification of tumstatin using mammalian expression sys- tem}

The coding sequence for tumstatin was also cloned in eu- karyotic expression vector pcBFT (Figure 2C). Human embryonic kidney cells (HEK-293) were transfected with recombinant plasmid pcBFT/tumstatin and selected using G-418 sulphate. About 2 liters of HEK-293 culture medium supernatant from cultured confluent cells containing the secreted tumstatin protein was pooled, concentrated and subjected to antitumstatin antibody based affinity chromatography. Different fractions obtained during purification process were analyzed by SDS-PAGE and coomassie staining (Figure 2D). The cytosolic extracts, soluble and insoluble protein obtained after 0$80 \%$ Ammonium sulphate precipitation were analyzed on a $10 \%$ SDS-PAGE gel (Figure 2F, lanes 2-4).

\section{Comparison of the three expression systems}

The soluble and insoluble tumstatin protein from three different expression systems ( $S f-9$ insect cells, E. coli and HEK293 cells) after dialysis was quantified and compared (Table 2). Expression of bulk amounts of tumstatin using bacterial system is less laborious and requires shorter time compared to Sf-9 insect cells and HEK-293 cell systems. The advantage of using bacterial system is that one can express bulk amounts of recombinant tumsatin protein in a shorter period of time. Although bacterial expression results in high yields of recombinant tumstatin protein, most of it is insoluble after dialysis. Refolding of the insoluble protein is laborious, and may also lead to improper folding of the proteins. Added to this the small fraction of soluble tumstatin protein obtained contains endotoxins, making the protein inapplicable for in-vitro studies. Hence expression of this extracellular matrix type IV collagen derived tumstatin protein in E. coli does not appear to be an ideal system for bulk production in its biologically active form. Further, the down stream processes involved in removal of endotoxins and protein refolding will greatly decrease the net yield.

HEK-293 cell expression system is too laborious, time consuming and expensive, besides bulk production of recombinant protein requires longer propagation of transfected HEK293 cells. Most of the protein is soluble which eliminates the need for protein refolding, and secretion of the protein into the medium supernatant is an added advantage. However, a large amount of culture media needs to be pooled for purification and the yield obtained is very less which is not sufficient to carryout in-vivo studies. For bulk production in HEK-293 cells, very large volumes of medium supernatant needs to be pooled and stored before purification, and this requires prolonged freezing and thawing affecting the yield of the tumstatin protein. In addition secreted tumstatin proteins may have short half-life and since the culture conditions were maintained at $37^{\circ} \mathrm{C}$, the over expressed tumstatin proteins are liable for degradation by proteases.

For purification of recombinant tumstatin protein using baculovirus expression system, a significant amout of time is required to develop the infectious virus, this is the only time consuming step involved but once the recombinant virus is made with high titer, the purification procedures are similar to bacterial system. About $95 \%$ of the recombinant protein expressed in $S f-9$ cells was soluble, while the protein expressed in HEK-293 cells and E. coli systems yielded $98 \%$ and $5 \%$ of total soluble protein respectively (Table 2 ). Several factors 


\section{Journal of Cancer Science \& Therapy - Open Access \\ JCST/Vol.1 Issue 1}

\begin{tabular}{|l|c|c|c|}
\hline Expression host & E. coli & HEK-293 cells & Sf-9 cells \\
\hline Culture size & 1 Liter & $\begin{array}{c}\text { 150mm x 20mm (2 liter medium } \\
\text { supernatant) }\end{array}$ & $\begin{array}{c}5 \text { plates }(150 \mathrm{~mm} \text { x } \\
20 \mathrm{~mm}) \sim 3 \times 10^{7} \\
\text { cells/plate }\end{array}$ \\
\hline Total protein & $\sim 700 \mathrm{mg}$ & $\sim 100 \mathrm{mg}$ & $\sim 350 \mathrm{mg}$ \\
\hline Column matrix & Ni-NTA agarose & Affinity chromatography & Ni-NTA agarose \\
\hline Column volume & $15 \mathrm{ml}$ & $10 \mathrm{ml}$ & $10 \mathrm{ml}$ \\
\hline $\begin{array}{l}\text { Total column bound } \\
\text { protein }\end{array}$ & $\sim 82 \mathrm{mg}$ & $\sim 60 \mathrm{mg}$ & $\sim 150 \mathrm{mg}$ \\
\hline $\begin{array}{l}\text { Total column eluted } \\
\text { protein }\end{array}$ & $\sim 27 \mathrm{mg}$ & $\sim 11 \mathrm{mg}$ & $\sim 62 \mathrm{mg}$ \\
\hline Insoluble protein & $\sim 23.6 \mathrm{mg}$ & $\sim 0.55 \mathrm{mg}$ & $\sim 1.35 \mathrm{mg}$ \\
\hline Soluble protein & $\sim 1.415 \mathrm{mg}$ & $\sim 5.516 \mathrm{mg}$ & $\sim 24.753 \mathrm{mg}$ \\
\hline$\%$ yield of soluble protein & $\sim 5.65 \%$ & $\sim 90.9 \%$ & $\sim 94.8 \%$ \\
\hline Endotoxin & + & - & - \\
\hline
\end{tabular}

Table 2: Comparing different expression systems for tumstatin expression and purification.
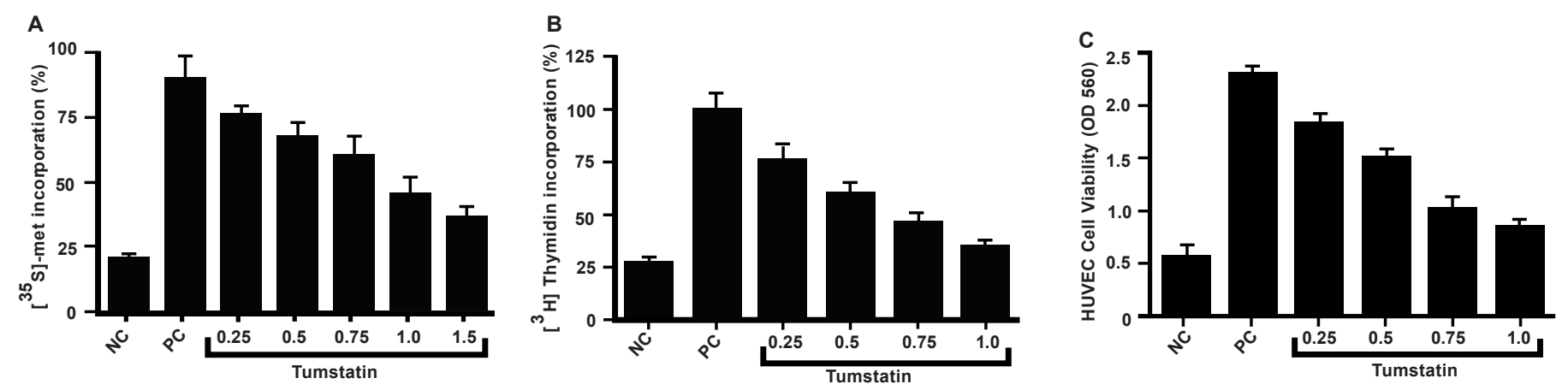

Figure 3: Translation, proliferation and cell viability assays using recombinantumstatin.

(A) Protein synthesis assay: Inhibition of protein synthesis by tumstatin in endothelial cells: Uptake of radioactive methionine in serum starved HUVECs after $24 \mathrm{hrs}$ incubation with media containing $10 \%$ FCS and various concentrations of tumstatin. Methionine incorporation in cell lysates was measured using liquid scintillation counter. The data shown is from three independent experiments. (B) Cell proliferation assay: The graph summarizes results from three independent experiments on the relative $\left[{ }^{3} \mathrm{H}\right]$-thymidine incorporation in HUVECs upon treatment with various concentrations tumstatin for 48 hr. $(\mathbf{C}) \mathbf{C e l l}$ viability assay using 3-(4,5-dimethylthiazol-2-yl)-2,5-diphenyl tetrazoliumbromide (MTT): The graph shows decrease in cell viability in HUVECs with increase in tumstatin concentration. A-C, NC represents negative control (cells grown in $0.1 \%$ FCS medium) and PC represents positive control (cells grown in $10 \%$ FCS medium).

such as high viral titer, higher $S f-9$ cell viability, temperature etc. needs to be optimized which will further enhance the net yield of the expressed tumstatin protein in baculovirus expression system. Our results indicate that bacculovirus expression system produces tumstatin protein without affecting its native properties, and in soluble quantities much higher than E. coli and HEK-293 systems. This baculovirus expressed purified soluble tumstatin was used in functional studies described below. The biologically activity and the quantity of the soluble tumstatin protein obtained using bacculovirus system was significantly higher compared to E. coli or HEK293 systems. Micromolar quantities of protein purified using baculovirus was effective in some of the angioinhibitory studies tested here.

\section{Functional characterization of the baculovirus expressed re-} combinant human tumstatin protein

Inhibition of protein synthesis in HUVECs was tested using baculovirus expressed recombinant tumstatin protein. Protein synthesis in HUVECs was inhibited in a dose dependent manner, where a concentration of $1.0 \mu \mathrm{M}$ tumstatin showed about $50 \%$ inhibition of protein synthesis (Figure 3A). Similarly, we also tested and observe dose dependent inhibion of HUVECs proliferation upon treatment with tumstatin (Figure 3B). Also using 3-(4,5-dimethylthiazol-2-yl)-2,5-diphenyl tetrazoliumbromide (MTT) assay was carried using different doses of tumstatin on endothelial cells and observed dose dependent inhibition of cell viability (Figure 3C).

Migration of endothelial cells has been shown to have an important early role in neovascularization (Kung et al., 2000; Sudhakar et al., 2005). Thus, we tested baculovirus expressed recombinant tumstatin for endothelial cell migration. Tumstatin showed a weaker inhibition of HUVECs migration across fibronectin coated membrane towards bFGF in a Boyden chamber compared to arresten (Figure 4A). The numbers of migrated endothelial cells towards underside of the Boyden chamber in three independent experiments were scored and assessed (Figure $4 \mathrm{~B}$ ). Interestingly arresten showed about $82 \%$ of migration inhibitory effect on HUVECs where as tumstatin showed about $25 \%$ of migration inhibition (Figure 4B). These results indicate that baculovirus expressed arresten is a more potent inhibitor of endothelial cell migration compared to tumstatin expressed in the same system.

Tube formation assay, another characteristic angioinhibitory activity of tumstatin was also tested. Addition of $1.0 \mu \mathrm{M}$ re- 
Citation: Boosani CS, Verma AK, Sudhakar A (2009) Validation of Different Systems for Tumstatin Expression and its in-vitro and invivo Activities. J Cancer Sci Ther 1: 008-018. doi:10.4172/1948-5956.1000002
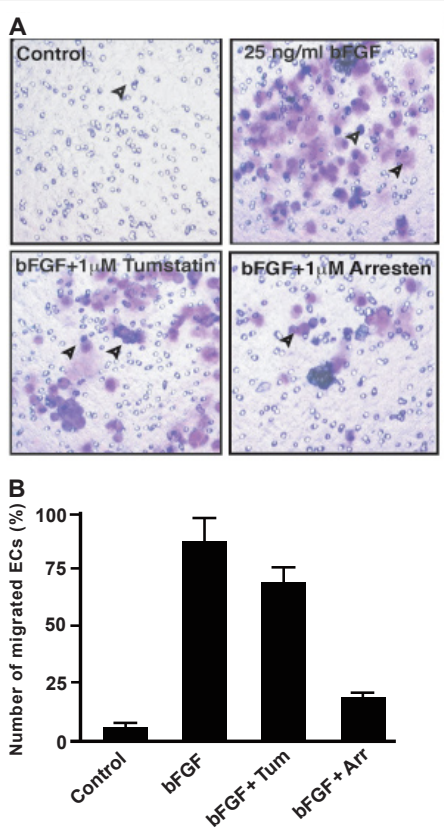

.
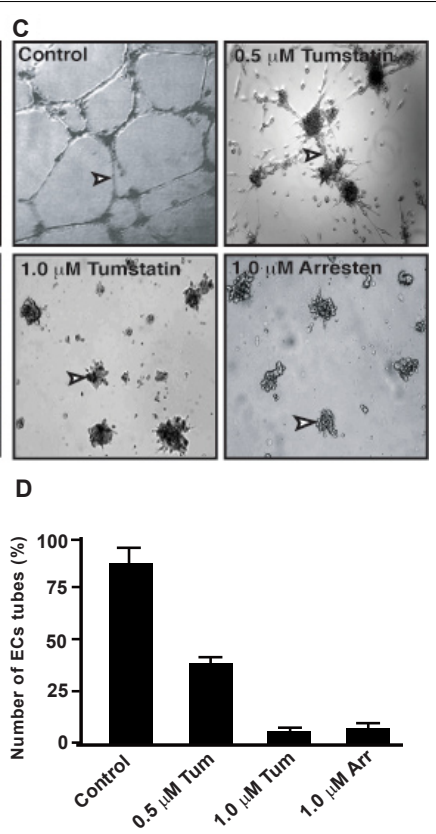

Figure 4: Migration and Tube formation assays.

(A) Migration assay: Photographs of HUVEC cells from the underside of Boyden chamber membrane. Number of cells migrated in ICM (incomplete medium) used as negative control. Number of migrated cells in ICM with $25 \mathrm{ng} / \mathrm{ml} \mathrm{bFGF}$ or with $\mathrm{bFGF}$ and $1 \mu \mathrm{M}$ tumstatin or $1 \mu \mathrm{M} \alpha 1$ (IV)NC1 were viewed using Olympus CK2 light microscope and representative fields (200x magnification) are shown. (B) Migration assessment assay: The graph displays average number of cells migrated in three independent experiments. (C) Tube formation assay: Tube formation was evaluated after $24 \mathrm{hrs}$ on Matrigel ${ }^{\mathrm{TM}}$ matrix with and without $1 \mu \mathrm{M}$ tumstatin or with $1 \mu \mathrm{M} \alpha 1(\mathrm{IV}) \mathrm{NC} 1$ proteins. Tube formation was visualized in Olympus CK2 light microscope and representative fields at 100x magnification are shown. (D) Tube formation assessment: The graph displays average number of tubes in three independent experiments. In $\mathrm{A}$ and $\mathrm{C}$, arrows indicate migrated endothelial cells and tube formation respectively.

combinant tumstatin protein to HUVECs culture media significantly inhibited tube formation on matrigel matrix (Figure 4C, middle panel). Previously we showed similar inhibition using arresten used as positive control here (Figure 4C, right) (Boosani and Sudhakar, 2006; Sudhakar et al., 2005). No significant effect of tumstatin on HUVECs proliferation was observed in cells that were not stimulated with FCS or bFGF indicating that tumstatin has no cytotoxic effects (data not shown).

\section{Signal transduction cascades induced by baculovirus ex- pressed tumstatin}

In endothelial cells, ligand upon binding to integrins induces phosphorylation of focal adhesion kinase (FAK), which serves as a platform for different downstream signals (Sudhakar et al., 2003; Zachary and Rozengurt, 1992). Recombinant baculovirus expressed purified tumstatin inhibited phosphorylation of FAK in endothelial cells cultured on fibronectin, confirming our previous observations that, this protein was working properly (Figure 5A) (Boosani et al., 2007; Maeshima et al., 2002; Sudhakar et al., 2003). Downstream to FAK, protein kinase B (PKB/Akt), phosphatidyl-3-kinase (PI3 kinase) plays an important role in mediating pathways involved in endothelial cell survival (Boosani et al., 2007; Hemmings, 1997; Maeshima et al., 2002; Shiojima and Walsh, 2002; Sudhakar et al., 2003). Akt is also known to regulate protein synthesis by phospho- rylating eukaryotic initiation factor 4E-binding protein (4E-BP1) via mTOR kinase (Downward, 1998; Maeshima et al., 2002; Miron et al., 2001; Sudhakar et al., 2003). Recombinant baculovirus expressed tumstatin inhibited sustained phosphorylation of Akt (Figure 5B), and activation of PI3 kinase in HUVECs cultured on fibronectin (data not shown). Downstream to Akt, mTOR directly phosphorylates eukaryotic initiation factor $4 \mathrm{E}(\mathrm{eIF} 4 \mathrm{E})$-binding protein (4E-BP1), and the unphosphorylated 4E-BP1 interacts with eIF4E inhibiting Capdependent protein synthesis (Boosani et al., 2007; Kumar et al., 2000; Maeshima et al., 2002; Pause et al., 1994; Sudhakar et al., 2003). Our studies using baculovirus expressed tumstatin confirmed the suppression mTOR activity and inhibition of 4E-BP1 phosphorylation in HUVECs (Figure 5C).
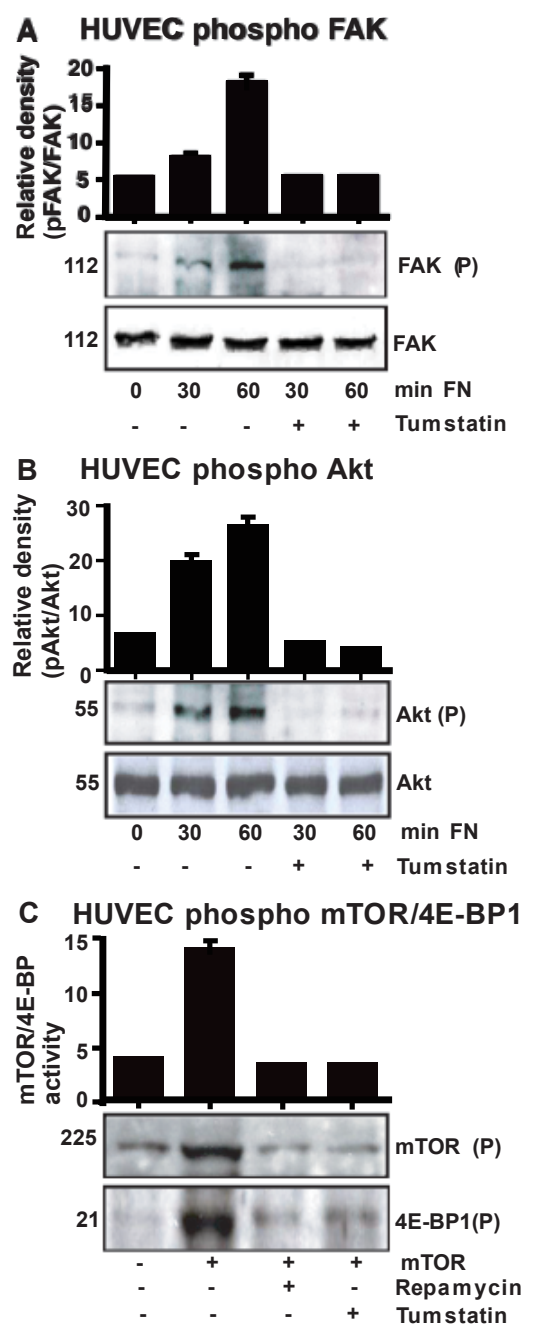

Figure 5: Regulation of tumstatin on the FAK/mTOR/4EBP1 Capdependent translation signaling.

(A) FAK phosphorylation: Immunoblots of phosphorylated FAK (upper blot) and total FAK (lower blot) showing inhibition of sustained phosphorylation by tumstatin. (B) Akt phosphorylation: Immunoblots of phosphorylated Akt (upper blot) and total Akt (lower blot) showing inhibition of sustained phosphorylation by tumstatin. (C) mTOR and 4E-BP1 phosphorylation: Autoradiograph of the auto-phosphorylated mTOR (upper blot) and phosphorylated 4E-BP1 (lower blot) from (HA)-mTOR transfected HUVECs. A-C. (P) and FN represents phosphorylation and fibronectin. A-C. Relative densities of phosphorylated FAK, Akt and mTOR was measured using NIH image software (top graph). 


\section{Journal of Cancer Science \& Therapy - Open Access \\ JCST/Vol.1 Issue 1}

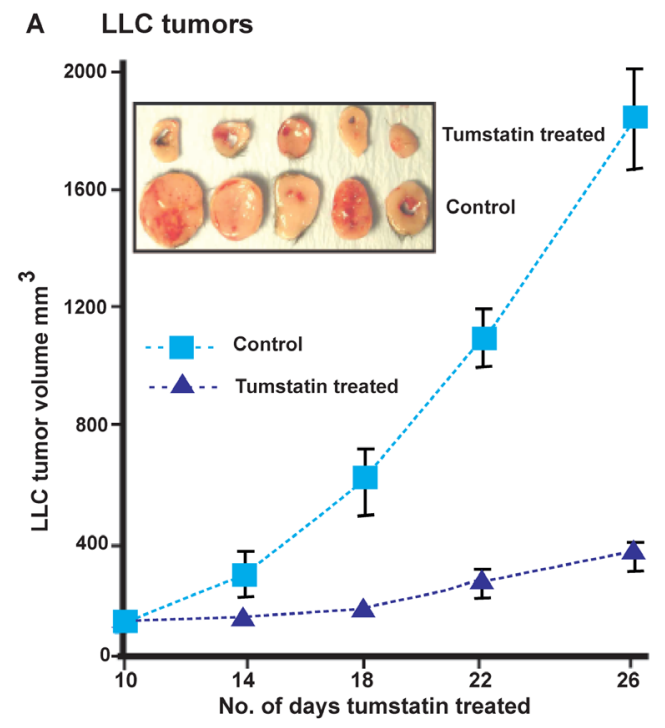

B No. of blood vessels

C No. of circulating ECs
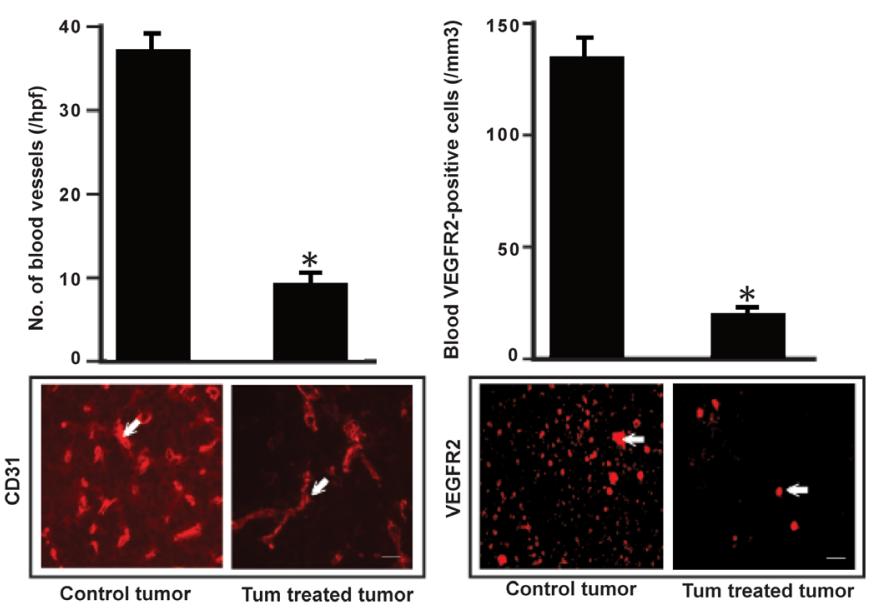

Figure 6: In-vivo tumor angiogenesis in $\mathrm{C} 57 \mathrm{BL} / 6$ mice.

(A) The graph showing the growth of C57BL/6 mice LLC tumors with and without tumstatin injections. The results are shown as mean \pm SEM. $p<$ 0.001 compared with tumor mice without tumstatin injection as control group. (B) Frozen sections $(4 \mu \mathrm{m})$ from control and tumstatin treated tumors were stained with anti-CD31 antibody and the number of CD31 positive blood vessels were counted, blood vessel quantification results were shown as the mean $\pm \mathrm{SE}$. ${ }^{*} \mathrm{p}<0.005$; compared to mice with and without treatment. (C) The circulating blood VEGFR2 positive endothelial cells in the tumor bearing control and tumstatin treated mice were quantification, results were shown as the mean \pm SE. $* p<0.005$; compared to mice with and without treatment. In panel B and C tumor CD-31 positive blood vessels and circulating blood endothelial cells were shown (arrow) in 10 fields at 200x magnification. Scale bar: $50 \mu \mathrm{m}$.

\section{Regulation of tumor angiogenesis by tumstatin in C57BL/6 mice}

Earlier researchers demonstrated that tumstatin halts the rate of tumor growth and angiogenesis in-vivo (Boosani et al., 2007; Miyoshi et al., 2006; Pedchenko et al., 2004). Here we have examined the growth of LLC tumors and tumor angiogenesis inhibition upon baculovirus expressed tumstatin treatment in tumor bearing C57BL/6 mice. Similarly as explained in our earlier studies, in this study LLC tumors were allowed to reach about $150 \mathrm{~mm}^{3}$ in size, and then $30 \mu \mathrm{g} /$ mouse/day tumstatin was administered intravenously (Figure 6A). The untreated control C57BL/6 mouse tumor group demonstrated an increased rate of tumor growth, numbers of CD31 positive blood vessels, where as the tumstatin treated experimental tumor mice demonstrated a significant inhibition of tumor growth and numbers of CD31 positive blood vessels (Figure 6B, tumstatin treated). To support inhibition of tumor growth and tumor angiogenesis, we have also measured circulating VEGFR2 positive endothelial cells from control and tumstatin treated tumor bearing mice blood, and the results conform significant inhibition of circulating endothelial cells upon tumstatin treatment. (Figure 6C, tumstatin treated). These results demonstrate that baculovirus expressed tumstatin is biologically active and regulating its angioinhibitory and antitumor activities in-vitro and in-vivo.

In summary, baculovirus expressed recombinant tumstatin protein showed its characteristic angioinhibitory and antitumor properties such as inhibition of FAK activation, inhibition of mTOR, 4E-BP1 and Cap dependent protein synthesis, inhibition of proliferation, tube formation and tumor growth. Our results suggest that baculovirus expression is an effective system to produce bulk quantities of tumstatin, and more importantly retaining the biological activity of the expressed protein. Since several endogenous angiogenesis inhibitors derived from type IV collagen non-collagenous domains are being investigated in cancer therapy and also in choriodial neovascularization related eye diseases, there is a need for a suitable expression system that produces recombinant tumstatin protein in high quality and yield. The comparitive expression of tumstatin in three different expression systems conformed that the baculovirus expression system is more usefull expression system for bulk production of soluble biologically active tumstatin for its preclinical and clinical use.

\section{Disclosure of potential conflicts of intrest}

\section{None}

\section{Acknowledgements}

We thank Dr. Rabin Read Harvard medical School, Boston; Dr. Nahum Sonenberg McGill University, Canada and Dr. Raghu Kalluri Beth Isreal Deconess Medical center, Boston for providing $S f-9$ cells, HA-mTOR/GST-4EBP-1 expression plasmids and pcBFT vectors.

Funding for this research work was provided by Flight Attendant Medical Research Institute Young Clinical Scientist Award Grant (\#062558), Dobleman Head and Neck Cancer Institute Grant (\#61905) and \#RO1CA143128, startup funds of Cell Signaling and Tumor Angiogenesis Laboratory at Boys Town National Research Hospital to AS. This work was also (in part) supported by startup funds of Structural \& Molecular Biology Laboratory, Tata Memorial Center, Advanced Center for Treatment, Research \& Education in Cancer to AKV.

\section{References}

1. Boosani CS, Mannam AP, Cosgrove D, Silva R, Hodivala-Dilke KM, et al. (2007) Regulation of COX-2 mediated signaling by alpha3 type IV noncollagenous domain in tumor angiogenesis. Blood 110: 1168-1177. »CrossRef » PubMed » Google Scholar

2. Boosani CS, Nalabothula N, Munugalavadla V, Cosgrove D, Keshamoun VG, et al. (2009a) FAK and p38-MAP kinase-dependent activation of apoptosis and caspase-3 in retinal endothelial cells by alpha1(IV)NC1. Invest Ophthalmol Vis Sci 50: 4567-4575. »CrossRef » PubMed » Google Scholar 
Citation: Boosani CS, Verma AK, Sudhakar A (2009) Validation of Different Systems for Tumstatin Expression and its in-vitro and invivo Activities. J Cancer Sci Ther 1: 008-018. doi:10.4172/1948-5956.1000002

3. Boosani CS, Narasimharao N, Sheibani N, Sudhakar A (2009b) Inhibitory effects of arresten on bFGF induced proliferation, migration and matrix metalloproteinase-2 activation in mouse retinal endothelial cells. Curr Eye Res [Epub ahead of print].

4. Boosani CS, Sudhakar A (2006) Cloning, purification, and characterization of a non-collagenous anti-angiogenic protein domain from human alpha1 type IV collagen expressed in Sf9 cells. Protein Expr Purif 49: 211-218. » CrossRef » PubMed » Google Scholar

5. Borza CM, Pozzi A, Borza DB, Pedchenko V, Hellmark T, et al. (2006) Integrin alpha 3 beta 1: a novel receptor for alpha 3 (IV) noncollagenous domain and a trans-dominant inhibitor for integrin alpha vbeta 3. J Biol Chem 281: 20932-20939. »CrossRef » PubMed » Google Scholar

6. Darland DC, D'Amore PA (1999) Blood vessel maturation: vascular development comes of age. J Clin Invest 103: 157-158. »CrossRef » PubMed » Google Scholar

7. Downward J (1998) Mechanisms and consequences of activation of protein kinase B/Akt. Curr Opin Cell Biol 10: 262-267. »CrossRef $»$ PubMed » Google Scholar

8. Gingras AC, Raught B, Sonenberg N (2001) Regulation of translation initiation by FRAP/mTOR. Genes Dev 15: 807-826. »CrossRef $»$ PubMed $»$ Google Scholar

9. Gunwar S, Ballester F, Kalluri R, Timoneda J, Chonko AM, et al. (1991) Glomerular basement membrane. Identification of dimeric subunits of the noncollagenous domain (hexamer) of collagen IV and the Goodpasture antigen. J Biol Chem 266: 15318-15324. »CrossRef » PubMed » Google Scholar

10. Han J, Ohno N, Pasco S, Monboisse JC, Borel JP, et al. (1997) A cell binding domain from the alpha 3 chain of type IV collagen inhibits proliferation of melanoma cells. J Biol Chem 272: 20395-20401. »CrossRef » PubMed » Google Scholar

11. Hemmings BA (1997) Akt signaling: linking membrane events to life and death decisions. Science 275: 628-630. $»$ CrossRef » PubMed » Google Scholar

12. Kalluri R (2003) Basement membranes: structure, assembly and role in tumour angiogenesis. Nat Rev Cancer 3: 422-433. " CrossRef » PubMed » Google Scholar

13. Kumar V, Sabatini D, Pandey P, Gingras AC, Majumder PK, et al. (2000) Regulation of the rapamycin and FKBP-target 1/mammalian target of rapamycin and cap-dependent initiation of translation by the c-Abl protein-tyrosine kinase. J Biol Chem 275: 1077910787. »CrossRef » PubMed » Google Scholar

14. Kung AL, Wang S, Klco JM, Kaelin WG, Livingston DM (2000) Suppression of tumor growth through disruption of hypoxia-inducible transcription. Nat Med 6: 1335-1340.» CrossRef » PubMed » Google Scholar

15. Maeshima Y, Colorado PC, Torre A, Holthaus KA, Grunkemeyer JA, et al. (2000) Distinct Anti-Tumor Properties of a Type IV Collagen Domain Derived from Basement Membrane. J Biol Chem 275: 21340-21348. » CrossRef » PubMed » Google Scholar

16. Maeshima Y, Sudhakar A, Lively JC, Ueki K, Kharbanda S, et al. (2002) Tumstatin, an endothelial cell-specific inhibitor of protein synthesis. Science 295: 140-143. » CrossRef » PubMed » Google Scholar

17. Marneros AG, Olsen BR (2001) The role of collagen-derived proteolytic fragments in angiogenesis. Matrix Biol 20: 337-345. »CrossRef » PubMed » Google Scholar

18. Martin GR, Evans MJ (1975) Differentiation of clonal lines of teratocarcinoma cells: formation of embryoid bodies in vitro. Proc Natl Acad Sci USA 72: 1441-1445. » CrossRef » PubMed » Google Scholar

19. Miron M, Verdu J, Lachance PE, Birnbaum MJ, Lasko PF, et al. (2001) The translational inhibitor 4E-BP is an effector of PI(3)K/ Akt signalling and cell growth in Drosophila. Nat Cell Biol 3: 596601. » CrossRef » PubMed » Google Scholar

J Cancer Sci Ther
20. Miyoshi T, Hirohata S, Ogawa H, Doi M, Obika M, et al. (2006) Tumor-specific expression of the RGD-alpha3(IV)NC1 domain suppresses endothelial tube formation and tumor growth in mice. Faseb J 20: 1904-1906. » CrossRef » PubMed » Google Scholar

21. Monboisse JC, Garnotel R, Bellon G, Ohno N, Perreau C, et al. (1994) The alpha 3 chain of type IV collagen prevents activation of human polymorphonuclear leukocytes. J Biol Chem 269: 2547525482. » CrossRef » PubMed » Google Scholar

22. Neilson EG, Kalluri R, Sun MJ, Gunwar S, Danoff T, et al. (1993) Specificity of Goodpasture autoantibodies for the recombinant noncollagenous domains of human type IV collagen. J Biol Chem 268: 8402-8405. » CrossRef » PubMed » Google Scholar

23. O’Reilly MS, Boehm T, Shing Y, Fukai N, Vasios G, et al. (1997) Endostatin: an endogenous inhibitor of angiogenesis and tumor growth. Cell 88: 277-285. » CrossRef » PubMed

24. O'Reilly MS, Holmgren L, Shing Y, Chen C, Rosenthal RA, et al. (1994) Angiostatin: a novel angiogenesis inhibitor that mediates the suppression of metastases by a Lewis lung carcinoma [see comments]. Cell 79: 315-328. » CrossRef » PubMed » Google Scholar

25. Pause A, Belsham GJ, Gingras AC, Donze O, Lin TA, et al. (1994) Insulin-dependent stimulation of protein synthesis by phosphorylation of a regulator of 5'-cap function. Nature 371: 762-767. »CrossRef » PubMed » Google Scholar

26. Pedchenko V, Zent R, Hudson BG (2004) Alpha(v)beta3 and alpha(v)beta5 integrins bind both the proximal RGD site and nonRGD motifs within noncollagenous (NC1) domain of the alpha3 chain of type IV collagen: implication for the mechanism of endothelia cell adhesion. J Biol Chem 279: 2772-2780. » CrossRef » PubMed » Google Scholar

27. Petitclerc E, Boutaud A, Prestayko A, Xu J, Sado Y, et al. (2000) New functions for non-collagenous domains of human collagen type IV. Novel integrin ligands inhibiting angiogenesis and tumor growth in vivo. J Biol Chem 275: 8051-8061. » CrossRef » PubMed » Google Scholar

28. Qian X, Wang TN, Rothman VL, Nicosia RF, Tuszynski GP (1997) Thrombospondin-1 modulates angiogenesis in vitro by up-regulation of matrix metalloproteinase-9 in endothelial cells. Exp Cell Res 235: 403-412. » CrossRef » PubMed » Google Scholar

29. Reynolds LE, Wyder L, Lively JC, Taverna D, Robinson SD, et al. (2002) Enhanced pathological angiogenesis in mice lacking beta3 integrin or beta 3 and beta5 integrins. Nat Med 8: 27-34. » CrossRef » PubMed » Google Scholar

30. Roth JM, Akalu A, Zelmanovich A, Policarpio D, Ng B, et al. (2005) Recombinant alpha2(IV)NC1 domain inhibits tumor cell-extracellular matrix interactions, induces cellular senescence, and inhibits tumor growth in vivo. Am J Pathol 166: 901-911. »CrossRef » PubMed » Google Scholar

31. Shahan TA, Ziaie Z, Pasco S, Fawzi A, Bellon G, et al. (1999) Identification of CD47/integrin-associated protein and alpha(v)beta3 as two receptors for the alpha3(IV) chain of type IV collagen on tumor cells. Cancer Res 59: 4584-4590. »CrossRef » PubMed » Google Scholar

32. Shiojima I, Walsh K (2002) Role of Akt signaling in vascular homeostasis and angiogenesis. Circ Res 90: 1243-1250. »CrossRef » PubMed » Google Scholar

33. Sudhakar A (2009) The matrix reloaded: new insights from type IV collagen derived endogenous angiogenesis inhibitors and their mechanism of action. J Bioequiv Availab 1: 52-62. » Google Scholar

34. Sudhakar A, Boosani CS (2007) signaling mechanisms of endogenous angiogenesis inhibitors derived from type IV collagen. Gene Regularulation System Biology 1: 217-226. »CrossRef » PubMed » Google Scholar

35. Sudhakar A, Boosani CS (2008) Inhibition of tumor angiogenesis by tumstatin: insights into signaling mechanisms and implications in 


\section{Journal of Cancer Science \& Therapy - Open Access \\ JCST/Vol.1 Issue 1}

cancer regression. Pharm Res 25: 2731-2739. » CrossRef » PubMed » Google Scholar

36. Sudhakar A, Krishnamoorthy T, Jain A, Chatterjee U, Hasnain SE, et al. (1999) Serine 48 in initiation factor 2 alpha (eIF2 alpha) is required for high-affinity interaction between eIF2 alpha(P) and eIF2B. Biochemistry 38: 15398-15405. »CrossRef » PubMed » Google Scholar

37. Sudhakar A, Nyberg P, Keshamouni VG, Mannam AP, Li J, et al. (2005) Human alpha1 type IV collagen NC1 domain exhibits distinct antiangiogenic activity mediated by alphalbeta 1 integrin. $\mathrm{J}$ Clin Invest 115: 2801-2810. » CrossRef » PubMed » Google Scholar

38. Sudhakar A, Ramachandran A, Ghosh S, Hasnain SE, Kaufman RJ, et al. (2000) Phosphorylation of serine 51 in initiation factor 2 alpha
(eIF2 alpha) promotes complex formation between eIF2 alpha(P) and eIF2B and causes inhibition in the guanine nucleotide exchange activity of eIF2B. Biochemistry 39: 12929-12938. »CrossRef » PubMed » Google Scholar

39. Sudhakar A, Sugimoto H, Yang C, Lively J, Zeisberg M, et al. (2003) Human tumstatin and human endostatin exhibit distinct antiangiogenic activities mediated by alpha vbeta 3 and alpha 5 beta 1 integrins. Proc Natl Acad Sci USA 100: 4766-4771. »CrossRef $»$ PubMed $»$ Google Scholar

40. Zachary I, Rozengurt E (1992) Focal adhesion kinase (p125FAK): a point of convergence in the action of neuropeptides, integrins, and oncogenes. Cell 71: 891-894. » CrossRef » PubMed » Google Scholar 